\title{
The Influence of External Load on the Performance of Microbial Fuel Cells
}

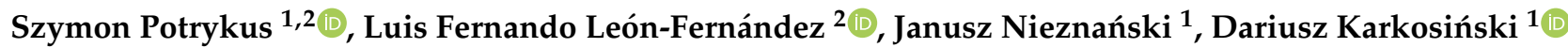 \\ and Francisco Jesus Fernandez-Morales $2, * \mathbb{B}$
}

1 Faculty of Electrical and Control Engineering, Gdańsk University of Technology, Gabriela Narutowicza 11/12, 80-233 Gdańsk, Poland; szymon.potrykus@pg.edu.pl (S.P.); janusz.nieznanski@pg.edu.pl (J.N.); darkarko@pg.edu.pl (D.K.)

2 Department of Chemical Engineering, ITQUIMA, University of Castilla-La Mancha, Av. Camilo Jose Cela, S/N, 13071 Ciudad Real, Spain; lfernando.leon@uclm.es

* Correspondence: fcojesus.fmorales@uclm.es; Tel.: +34-926-295300 (ext. 6350)

Citation: Potrykus, S.;

León-Fernández, L.F.; Nieznański, J.; Karkosiński, D.; Fernandez-Morales, F.J. The Influence of External Load on the Performance of Microbial Fuel Cells. Energies 2021, 14, 612. https:// doi.org/10.3390/en14030612

Academic Editor: Chikashi Sato

Received: 19 December 2020

Accepted: 22 January 2021

Published: 26 January 2021

Publisher's Note: MDPI stays neutral with regard to jurisdictional claims in published maps and institutional affiliations.

Copyright: (c) 2021 by the authors. Licensee MDPI, Basel, Switzerland. This article is an open access article distributed under the terms and conditions of the Creative Commons Attribution (CC BY) license (https:/ / creativecommons.org/licenses/by/ $4.0 /)$.

\begin{abstract}
In this work, the effect of the external load on the current and power generation, as well as on the pollutant removal by microbial fuel cells (MFCs), has been studied by step-wise modifying the external load. The load changes included a direct scan, in which the external resistance was increased from $120 \Omega$ to $3300 \Omega$, and a subsequent reverse scan, in which the external resistance was decreased back to $120 \Omega$. The reduction in the current, experienced when increasing the external resistance, was maintained even in the reverse scan when the external resistance was step-wise decreased. Regarding the power exerted, when the external resistance was increased below the value of the internal resistance, an enhancement in the power exerted was observed. However, when operating near the value of the internal resistance, a stable power exerted of about $1.6 \mu \mathrm{W}$ was reached. These current and power responses can be explained by the change in population distribution, which shifts to a more fermentative than electrogenic culture, as was confirmed by the population analyses. Regarding the pollutant removal, the effluent chemical oxygen demand (COD) decreased when the external resistance increased up to the internal resistance value. However, the effluent COD increased when the external resistance was higher than the internal resistance. This behavior was maintained in the reverse scan, which confirmed the modification in the microbial population of the MFC.
\end{abstract}

Keywords: microbial fuel cell; bioelectricity generation; external resistance

\section{Introduction}

The increasing world population and the rising standard of living are the main reasons for the increase in energy demand. The rise in energy consumption is accompanied by the deterioration of the natural environment. With the aim to protect the environment, a number of steps have been taken to minimize the negative effects of energy production. During the last few years, more attention has been focused on alternative energy sources that are abundant and environment-friendly [1]. Unfortunately, energy production from some renewable energy sources strongly depends on atmospheric conditions, which makes the sources hardly appropriate for addressing peak demands. Because of this, continuous energy supply cannot be ensured only by these sources, and novel renewable energy technologies are required.

Amongst these novel renewable technologies, fuel cells are a particularly promising option. The main advantage thereof over the most widespread renewable energy sources, such as sunlight or wind energy, is the possibility of uninterrupted operation, owing to the fact that energy production only depends on the fuel supply. Additionally, because of the direct conversion of chemical energy into electricity, fuel cells offer higher efficiencies than traditional generators or power units [2]. 
An attractive category of fuel cells is microbial fuel cells (MFCs). In the MFCs, microbial cultures can be involved in the processes of oxidation and reduction. In most cases, an active microbial culture located at the anode oxidizes organic substrates releasing electrons to the anode and protons to the liquid bulk. The electrons flow through an external electrical circuit, generating an electric current, and the protons are transported to the cathode through the membrane. At the cathode, the electrons and protons are used to reduce an oxidant, usually oxygen [3]. The major limitation of MFC technology is its low-density of power generation [4]. However, MFC power density can be increased by optimizing operating conditions, such as COD, $\mathrm{pH}$, flow rate, and temperature, or configuration options, such as the electrodic area and external resistance. [5-14]. One of the most relevant variables is external resistance. This is because external resistance controls the current and cell voltage exerted [15]. A high external resistance results in a high cell voltage and low current; the opposite is observed when operating with low external resistance. According to Jacobi's Law, the maximum external power will be obtained when the external resistance equals the internal resistance of the MFCs [16]. Taking into account that one of the main problems of MFC technology is maximizing the power output, the study of the effect of external resistance thereon is very relevant for engineers [17-19].

In the literature, it has been described as the effect of the external load over batch operated MFCs [20]. However, for full-scale implementation, as well as for process automatization, it is necessary to study the influence of the external load over MFCs operating in the continuous mode. Thus, this paper focused on the study of the influence of external resistance over the performance of MFCs. Attention was paid to electricity production, fuel consumption, and the microorganism's population of the anodic compartment.

\section{Materials and Methods}

In order to study the influence of the external load on the performance of an MFC operating continuously, different external loads were connected to the MFC. These experiments were carried out at a constant influent flow rate of $7.2 \mathrm{~L} / \mathrm{d}$. The initial external resistance, $120 \Omega$, was step-wise increased to $560,1000,1500,2200,2700$, and $3300 \Omega$ in the direct scan. After that, the value of the external resistance was step-wise decreased back to the initial external value of $120 \Omega$. The duration of the entire experiment was 92 days.

\subsection{Experimental Set-Up}

In this work, a two-chambered MFC was used. Cathodic and anodic graphite plate chambers were used, the volume of the cathodic and the anodic chambers were $0.5 \mathrm{~cm}^{3}$ and $0.95 \mathrm{~cm}^{3}$, respectively. The compartments of the MFC were separated by a Sterion ${ }^{\circledR}$ proton exchange membrane (PEM), $180 \mu \mathrm{m}$ thick, with an ion exchange capacity of 0.9 $0.02 \mathrm{meq} \mathrm{g}^{-1}$, ionic conductivity of $8 \times 10^{-2} \mathrm{~S} / \mathrm{cm}$, and electronic conductivity of $<10^{-10}$ $\mathrm{S} \mathrm{cm}^{-1}$. As anodic and cathodic electrodes, Toray carbon papers TGPH-120 obtained from E-TEK (Somerset, NJ, USA) were used. The projected superficial area of the anodic electrode was $4.65 \mathrm{~cm}^{2}$, and that of the cathodic electrode was $2.85 \mathrm{~cm}^{2}$. The anodic and cathodic electrodes contained $20 \%$ and $10 \%$ of Teflon, respectively, in order to improve their mechanical properties, causing a very small drop in the electrochemical performance. A cathodic catalytic layer of $0.5 \mathrm{mg} \mathrm{Pt} / \mathrm{cm}^{2}$ loading was deposited, with the aim of enhancing the electrode performance [21]. The electrodes and membranes were coupled as a membrane-electrode assembly (MEA), which was performed according to the literature [5]. The cathode and the anode were connected by means of an external resistance $\left(R_{\mathrm{ext}}\right)$, which was modified in the different experiments. The range of loads studied in this work was selected in order to include the value of internal resistance, $2210 \Omega$, and values higher and lower than that of the internal resistance. Because of this, the range from $120 \Omega$ to $3300 \Omega$ was selected-taking into account the literature [22]. Figure 1 presents the set-up used in this work. 


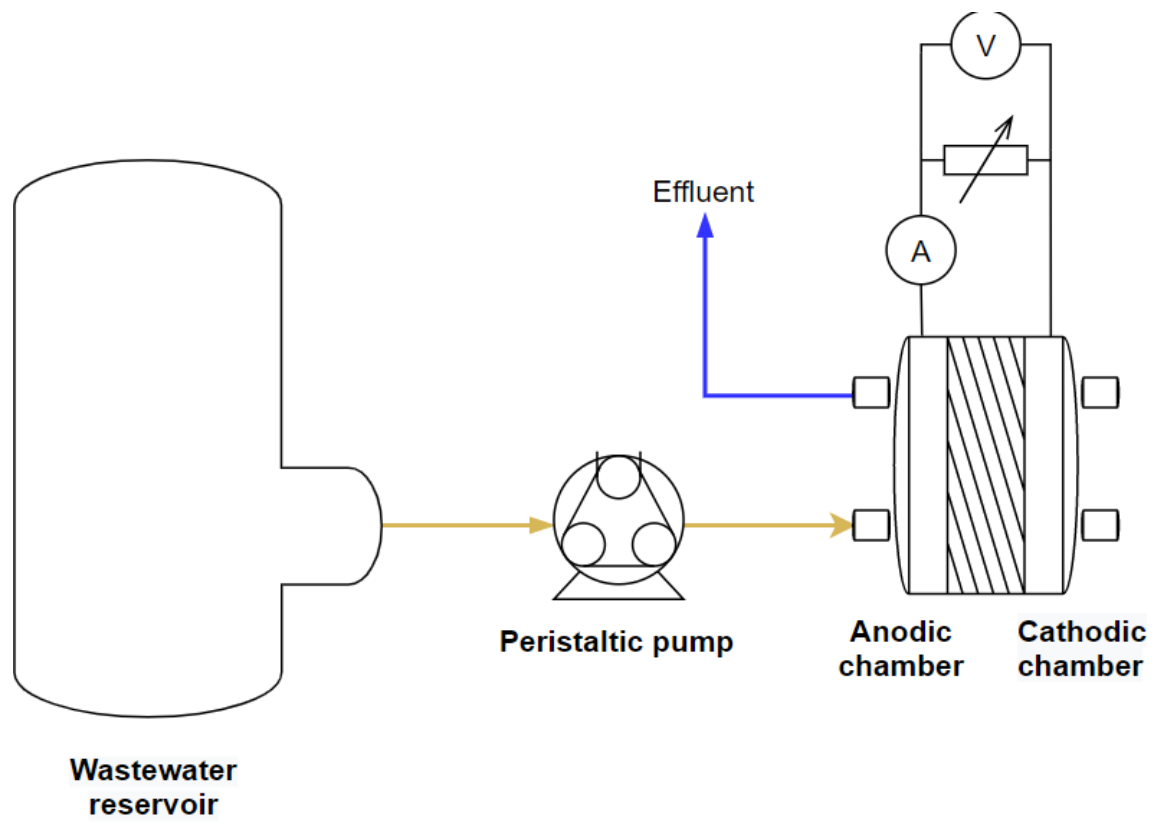

Figure 1. Set-up configuration.

The anodic compartment was inoculated with an electrogenic culture, as previously described in the literature [23]. The MFC used in this study was operated in a continuous mode by feeding the anodic chamber with synthetic wastewater at a flow rate of $0.5 \mathrm{~cm}^{3} / \mathrm{min}$. The substrates contained in the synthetic wastewater are presented in Table 1 . With the aim to ensure reproducible conditions, the synthetic wastewater was sterilized for $30 \mathrm{~min}$ at $105^{\circ} \mathrm{C}$ [24]. An air-breathing cathode was used because of its high performance, according to the literature [25].

Table 1. Composition of the synthetic wastewater.

\begin{tabular}{cc}
\hline Component & Concentration $(\mathrm{mg} / \mathrm{L})$ \\
\hline Fructose & 161.0 \\
Glucose & 161.0 \\
$\mathrm{NaHCO}_{3}$ & 111.0 \\
$\left(\mathrm{NH}_{4}\right)_{2} \mathrm{SO}_{4}$ & 74.2 \\
$\mathrm{KH}_{2} \mathrm{PO}_{4}$ & 44.5 \\
$\mathrm{MgCl}_{2}$ & 37.1 \\
$\mathrm{CaCl}_{2}$ & 30.7 \\
$\left(\mathrm{NH}_{4}\right)_{2} \mathrm{Fe}\left(\mathrm{SO}_{4}\right)_{2}$ & 3.1 \\
\hline
\end{tabular}

\subsection{Characterization Techniques}

The MFC operation was continuously monitored by means of a digital multimeter connected to the $R_{\text {ext }}$. The potential $(\mathrm{V})$ was directly related to the electrical current (I) between the terminals of the external load by the Ohm's law. The power was calculated using the relation between I and V. In this set-up, the electrical current was generated because of the anodic oxidation of the substrates contained in the synthetic wastewater fed to the MFC. This oxidation process was monitored by determining the COD removal rate $\left(\mathrm{r}_{\mathrm{COD}}\right)$, measured as $\mathrm{mg} \mathrm{COD} / \mathrm{h}$, and the COD removal percentage (\% COD) [26]. These parameters can be calculated according to Equations (1) and (2), respectively, where $\mathrm{F}$ is the influent flow rate, $\triangle \mathrm{COD}$ is the COD removed from the wastewater, and $\mathrm{COD}_{\mathrm{o}}$ is the initial COD concentration of the wastewater, about $343 \mathrm{mg} / \mathrm{L}$.

$$
\mathrm{r}_{\mathrm{COD}}=\mathrm{F} \cdot \Delta \mathrm{COD}
$$




$$
\% \mathrm{COD}=\frac{\Delta \mathrm{COD}}{\mathrm{COD}_{o}} \cdot 100
$$

The COD and volatile suspended solid (VSS) concentrations in the anodic effluent were measured using spectrophotometric and gravimetric methods, respectively, according to the literature [27]. The $\mathrm{pH}$ was determined by using a PCE-228 $\mathrm{pH}$ meter. The biomass populations were characterized using Matrix-Assisted Laser Desorption/Ionization coupled to a time of flight ion detector (MALDI-TOF) Axima Assurance from Shimadzu (Kioto, Japan) equipment. The matrix solutions were prepared following the procedure described in the literature [5]. Additionally, the concentrations of acetic, propionic, and butyric acids in the effluents were determined by gas chromatography (Perkin Elmer) with a flame ionization detector (FID), following the procedure described in the literature [28].

\section{Results and Discussion}

In this work, the influence of the external resistance on the electricity production, fuel consumption, wastewater treatment capacity, and microbial culture population was evaluated. For this, the external resistance was step-wise increased from $120 \Omega$ to 560 , $1000,1500,2200,2700$, and $3300 \Omega$. The external resistance of $3300 \Omega$ was selected in order to ensure that the upper limit of the resistance range is significantly above the internal resistance of the MFC used in this study, the latter being about $2200 \Omega$. After that, the value of the external resistance was step-wise decreased back to the initial resistance value of $120 \Omega$ in order to analyze the effect of reducing the external resistance of the MFC.

With the aim of ensuring the reproducibility of the tests, each external resistance value was kept in the MFC for 7 days in order to ensure a steady state response. Once the response reached the steady state, the electrical performance of the MFC as well as the $\mathrm{pH}$, COD, and microorganisms' concentration of the effluent were determined.

\subsection{External Load Effect on Electricity Production}

The influence of the external load over the electricity production was studied by taking into account the current and power exerted.

\subsubsection{Current Generated by the Cell}

Figure 2 presents the electrical current exerted by the cell when operating at different external loads. In order to ensure reproducibility, the results were recorded once they had reached the steady-state response. In this figure, it can be observed that the current decreased when the external load increased. This trend can be explained because the external load controls the ratio between the current generation and the cell voltage [9]. In the literature, it has been described that a high external resistance results in high cell voltages and low currents [18]. The greatest changes were obtained when the resistance increased from 560 to $1500 \Omega$, reaching a minimum current of $0.02 \mathrm{~mA}$ when an external resistance of $3300 \Omega$ was applied. Once the direct scan had been finished, a reverse scan was performed with the aim to compare the intensity obtained when the external resistance was step-wise increased and then step-wise decreased. During the reverse scan, contrary to the expectations, the intensity exerted by the MFCs did not increase. The current was kept almost constant around $0.02 \mathrm{~mA}$, independently of the external resistance applied. Because of this, the current generated by the MFC for each external resistance was higher in the direct than in the reverse scan. In other words, after operation with high external loads, the exerted intensity decreased. This behavior indicated that the system had irreversibly changed because of the exposition to high external resistances. This change only could be explained by a change in population distribution. In the literature, it has been suggested that external load changes influence the growth and population distribution in the biotic compartments of the MFC [29]. In order to ratify this, the microbial population was analyzed by means of MALDI-TOF, observing the apparition of Clostridium when the external resistance increased. This behavior has also been identified in other recent research works [20]. These fermenter microorganisms present a higher growth rate, about $0.1 \mathrm{~h}^{-1}$ [30], than the 
electrogenic ones, about $0.05 \mathrm{~h}^{-1}$ [31], which could explain why the population did not return to the initial conditions when the external resistance was decreased.

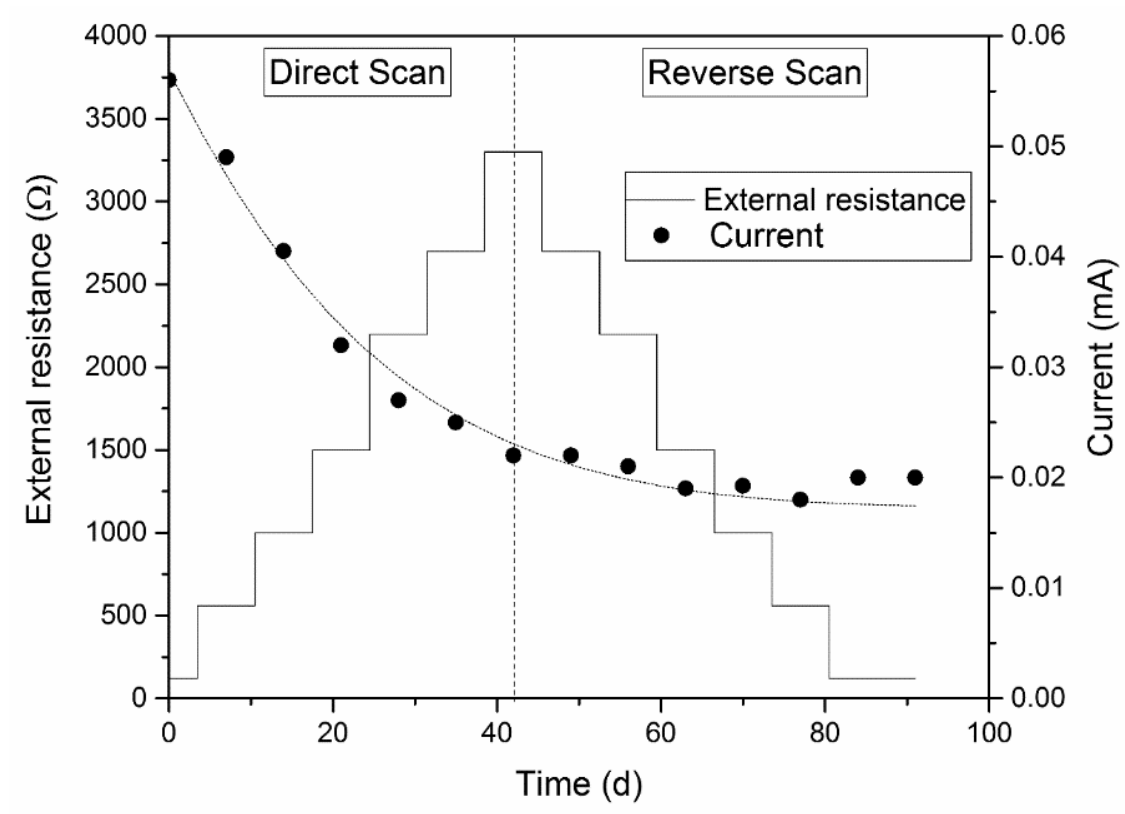

Figure 2. Current exerted by the microbial fuel cells (MFC) at every external resistance.

\subsubsection{Power Generated by the Cell}

The Jacobi Theorem states that the maximum power can be obtained when the external resistance equals the internal one. Jacobi published the maximum power transfer theorem in 1840, establishing that the efficiency of the power transfer can be defined as indicated in Equation (3). The efficiency is only $50 \%$ when the maximum power transfer is achieved, but approaches $100 \%$ as the external resistance approaches infinity.

$$
\eta=\frac{R_{\text {External }}}{R_{\text {External }}+R_{\text {Internal }}}
$$

Because of this, a polarization curve was carried out to determine the internal resistance of the MFC. From this analysis, the internal resistance was determined to be $2210 \Omega$. In order to verify the Jacobi Theorem, Figure 3 presents the power generated at every external resistance.

As can be seen in Figure 3, when increasing the external resistance from 120 to $560 \Omega$, a great increment in power exerted was observed. The power exerted increased from 0.4 to $1.4 \cdot \mu \mathrm{W}$. Then, the subsequent step-wise increments in the external resistance slightly increased the power exerted, reaching a maximum at about $2200 \Omega$, exerting $1.6 \mu \mathrm{W}$. This value of the power exerted was the maximum value obtained with the MFC used in this work, ratifying the Jacobi Theorem. When the external resistance was step-wise decreased, a significant reduction in the power exerted was observed, from 1.6 to $0.05 \mu \mathrm{W}$. It must be remarked that this behavior generated a hysteresis loop. Because of this, the power exerted for each external resistance was always higher in the direct scan, when the external resistance was step-wise increased, compared with operating in the reverse scan, when the external resistance was step-wise decreased. In the literature, it has been proposed that these changes could be explained by changes in the distribution of the microbial population of the culture when the external load changed [17]. This change in the microbial population could be the reason for a reduction in the power exerted after the operation under high external resistance. In the literature, it has been described that the differences observed in the anodic potentials when the MFC is operated at different external loads act as a selection force for the different electrogenic microorganisms [32]. These changes in the microbial distribution could modify the activation losses and the 
internal resistance of the anode, which are a function of the electrochemical activity of the anodic electrogenic microorganisms [33]. In this work, as described above, the microbial population distribution changed after the experiments, showing significant growth of fermenter microorganisms, mainly from the Clostridium genus.

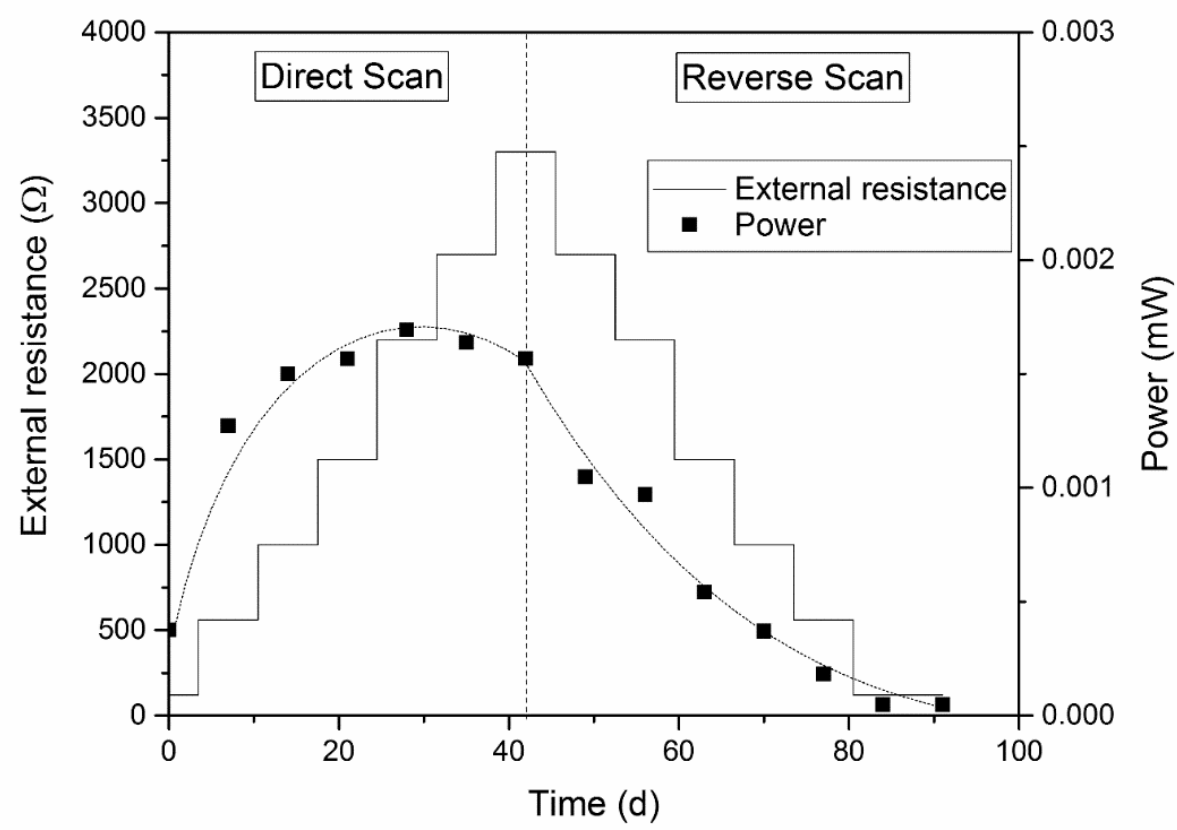

Figure 3. The power exerted by the MFCs at every external resistance.

\subsection{External Load Effect on Fuel Consumption}

As the changes in the external resistance influenced the electrical performance of the microbial culture of the MFC, we evaluated its influence over fuel consumption. It must be stated that in this case, the fuel was the biodegradable substrates contained in the synthetic wastewater. To evaluate the fuel consumption, the chemical oxygen demand (COD) of the synthetic wastewater was determined before and after its reaction in the MFC. Figure 4 presents the COD removal as a function of the external resistance applied. As can be seen, the fuel consumption slightly increased when the external resistance was increased up to the value of the internal resistance of the MFC, namely $2200 \Omega$. However, when the external resistance was higher than this value, the fuel consumption started to decrease. This decrement was maintained, even when the external resistance values were decreased during the reverse scan. Taking into account that electricity production also decreased, we decided to determine the Coulombic efficiency (CE). CE is a measurement that indicates the percentage of electron equivalents converted into electricity when oxidizing fuel in the MFC. From the values of the CE obtained, it was observed that the CE decreased along with the experiments. This behavior could be explained by changes in the population's distribution of the microbial culture previously described. In this case, the reduction in the $\mathrm{CE}$ could be explained because the growth of non-electrogenic microorganisms outcompetes the growth of the electrogenic ones. 


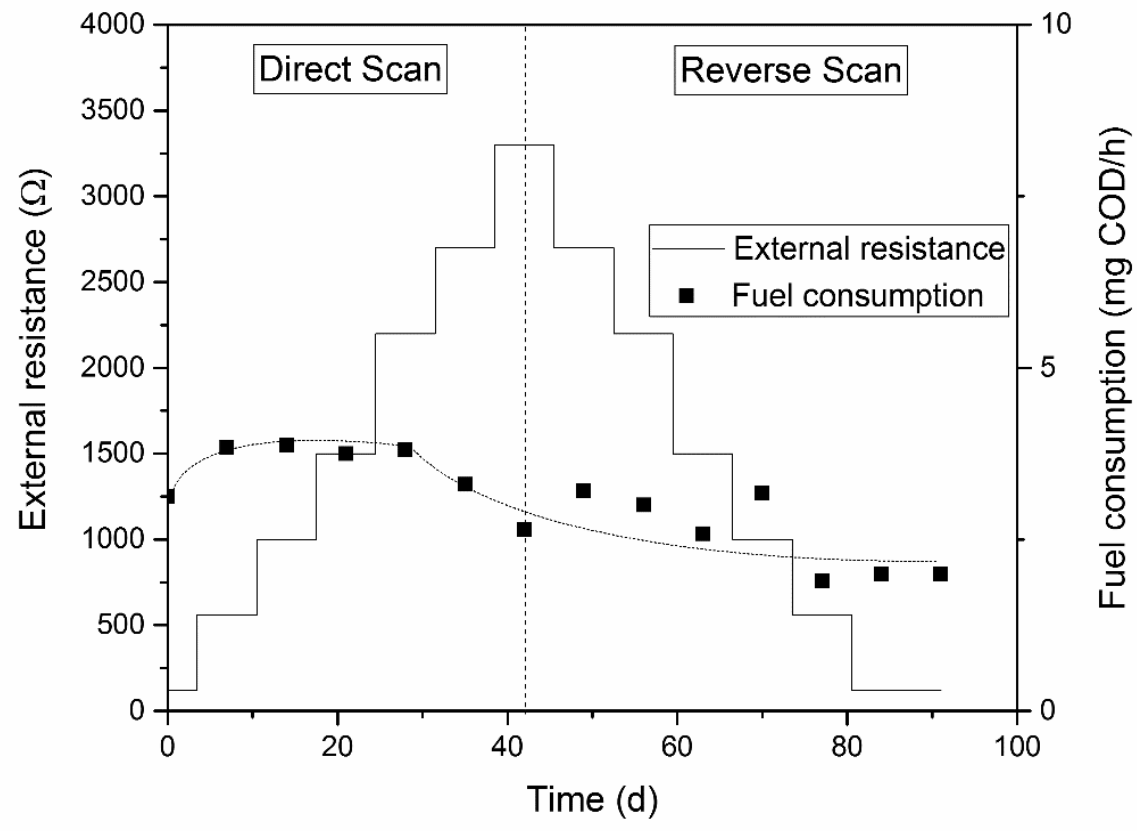

Figure 4. Fuel consumption in a steady state at every external resistance.

In order to study the transformations of the fuel, the $\mathrm{pH}$, fermentation product generation, and the biomass concentration in the effluent, measured as VSS, were determined along with the experiments. In Figure 5, the VSS and $\mathrm{pH}$ as a function of external resistance are shown.

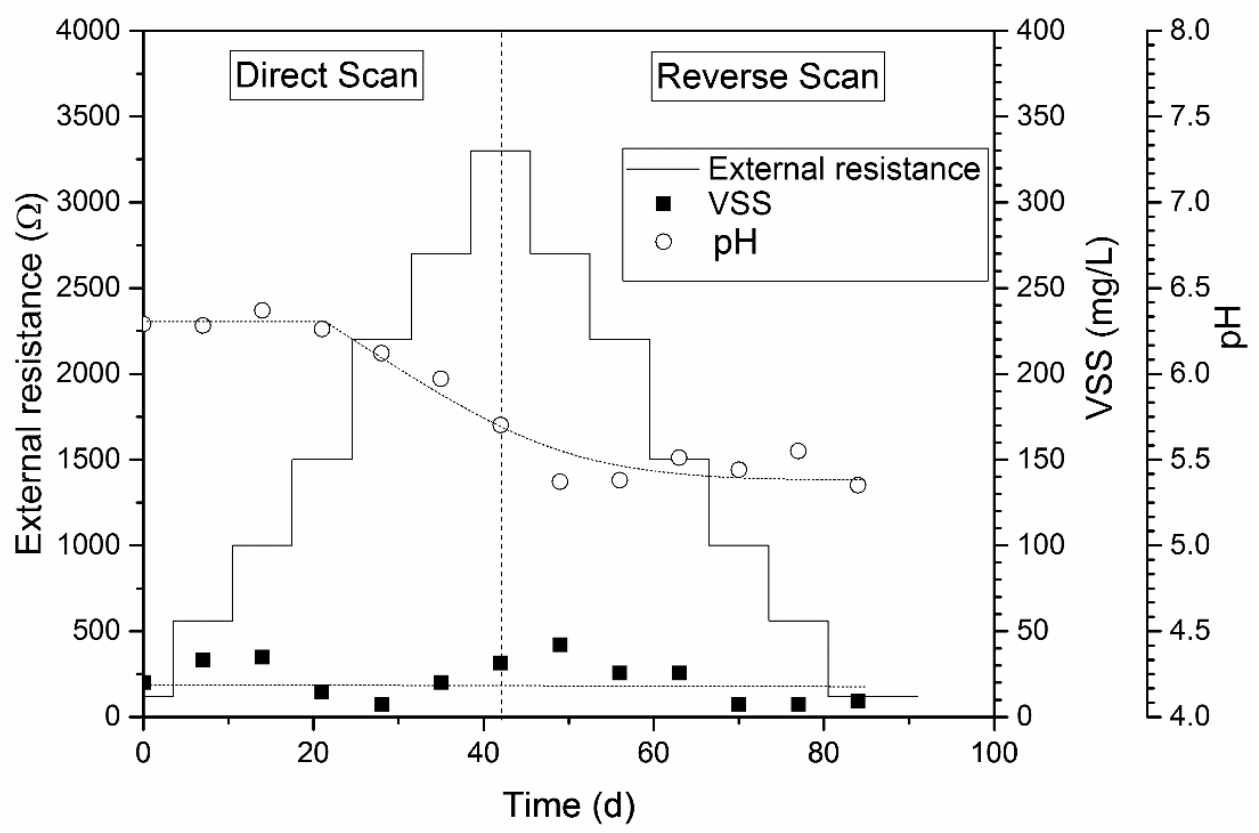

Figure 5. Volatile suspended solids' concentration and $\mathrm{pH}$ of effluent at every external resistance.

As can be seen in Figure 5, the effluent microorganisms' concentration remained unaltered when the external resistance was modified. However, taking into account that the current generated at high external resistances was lower, it can be concluded that the population shifted to a less electrogenic culture. With regards to $\mathrm{pH}$, it plays a key role in the MFC performance. This is because the $\mathrm{pH}$ affects the microbial metabolic reactions, and could even stop the vital microbial functions if the microorganisms are exposed to $\mathrm{pH}$ values out of their operational $\mathrm{pH}$ range [34]. Thus, most MFCs operate at a neutral 
$\mathrm{pH}$ to maximize microbial growth [35]. The $\mathrm{pH}$ can influence oxidative metabolisms and, in turn, affect the proton generation mechanisms and the electron transference to the electrode [36]. In Figure 5, it can be seen that the $\mathrm{pH}$ was maintained at a constant, around 6.3, when the external resistance was lower than $2200 \Omega$; this $\mathrm{pH}$ is an optimal $\mathrm{pH}$ for the growth of the electrogenic microorganisms. Then, when the external resistance was increased over $2200 \Omega$, the $\mathrm{pH}$ decreased until 5.8. These results indicate an enhancement of acidogenic metabolisms when the external resistance overcomes the value of the internal one, $2200 \Omega$. Then, in the reverse scan, when the external resistance was decreased from 3300 to $120 \Omega$, the $\mathrm{pH}$ was maintained at acidic values, out of the optimum range of the electrogenic microorganisms. This behavior could be explained by the development of acidogenic microorganisms, which released volatile fatty acids (VFA) as result of the acidogenic fermentation of the substrate, mainly when operating at an external resistance higher than the internal one. These results indicate an irreversible change in the population distribution during the direct scan, which was maintained even during the reverse scan. This hypothesis was ratified by the MALDI-TOF analysis previously performed, which identified the appearance of Clostridium microorganisms when the value of the external resistance overcame the value of the internal one.

In the literature, Pinto and al. predicted that the development of an electroactive microbial culture could only be achieved when the external resistance value was under the value of the internal one. In this way, the lower values of the external resistance facilitated the electron transfer process, assisting the development of the electrogenic culture [37]. In contrast, high values of external resistance facilitate the development of non-electrogenic cultures. To verify this hypothesis, the VFAs released to the liquid bulk were analyzed.

Finally, in order to determine if VFA generation caused the drop of $\mathrm{pH}$, the effluent VFA concentration was determined. From the analysis, acetic and propionic acid were identified as the main VFAs contained in the anodic effluent. In Figure 6, the VFA concentrations for each external load studied are presented. The acetic acid concentration was very similar, about $0.8 \mathrm{mM}$, for all of the external loads studied. However, the propionic acid concentration significantly increased from 0 to $0.6 \mathrm{mM}$ when the external resistance was increased. Then, when the external resistance was decreased, a slight reduction in the propionic concentration was observed. As a result, an increasing and then slightly decreasing VFA concentration was observed, as presented in Figure 6. The increase in the VFA concentration, and its dissociation, explained the observed $\mathrm{pH}$ drop [28].

Figures 5 and 6 show that the increment of external resistance facilitated the acidogenic metabolisms, enhancing the growth of fermentative microorganisms without electricity generation. In the literature, Rismani-Yazdi et al. observed that the total VFA concentration of the anolyte increased with the increase in the external resistance, yielding the highest VFA concentrations when operating with the maximum external resistance [33]. These observations also agree qualitatively with microbial population modeling and experimental works previously published by Picioreanu et al., which showed that an increased external resistance favors the growth of the anaerobic microorganisms [38,39]. The increased production of VFA indicates a shift from an electrogenic culture to a fermentative one when the system operates under higher external resistances. This could be explained by taking into account that the higher the external resistance, the more difficult the electron transference to the anode and, therefore, the lower the electron transfer rate. This difficulty causes a lower growth rate for the electrogenic microorganisms, which was reflected in the lower current and the electrical energy generation [18].

In order to identify the electrogenic and non-electrogenic contributions to the fuel consumption in the MFCs, a mass fuel balance based on COD measurements was carried out. Taking into account the influent COD, the effluent COD, and considering the VFA COD contribution to the effluent, the net fuel consumption in the electrogenic and fermentative metabolisms was determined. In Figure 6, the different COD contributions are presented as a function of external resistance. 


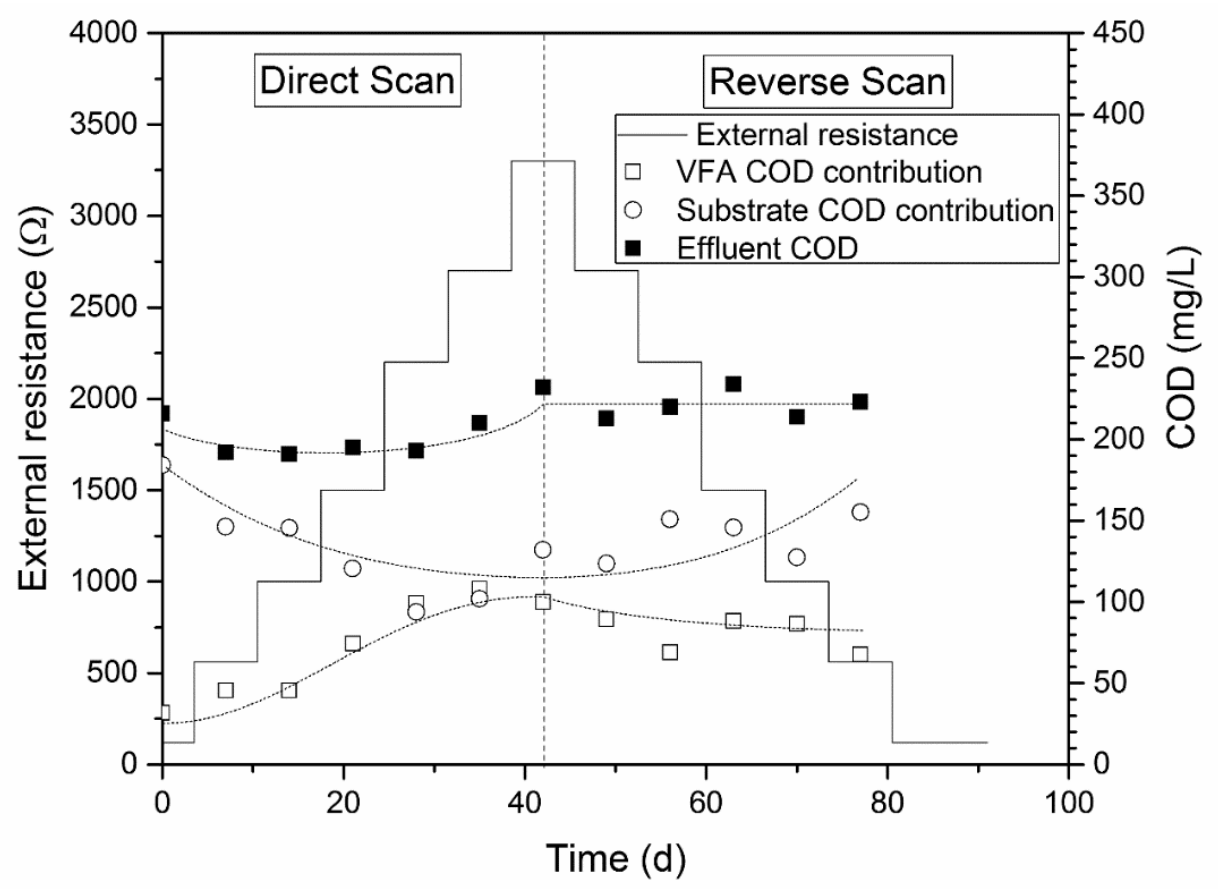

Figure 6. Acid chemical oxygen demand (COD), substrate COD, and total COD of the effluent at every external resistance.

As explained above, the effluent COD decreased when increasing the external resistance. On the one hand, the raw substrate COD in the effluent decreased from 200 to $100 \mathrm{mg} \mathrm{O}_{2} / \mathrm{L}$ when the external resistance increased from 120 to $3300 \Omega$, because of the contribution of the fermentative non-electrogenic metabolisms. The fermentative metabolisms consumed a significant amount of COD, but also released VFA, contributing to the COD of the liquid bulk. In Figure 6, it is shown that the VFA contribution to the effluent COD increased when the external resistance of the system increased.

Thus, it can be concluded that the increment of external resistance causes an increment of VFA production, and a decrease in the effluent substrate concentration because of the contribution of non-electrogenic fermentative culture.

In order to evaluate the net fuel consumption, the substrate removal rate was calculated, ranging in values from 3 to $4.5 \mathrm{mg} / \mathrm{h}$ when the external resistance was increased from 120 to $3300 \Omega$. This increase can be explained by the non-electrogenic metabolisms observed at higher external resistances. Hence, the maximum pollutant removal from the wastewater of the MFC was obtained when operating at the highest external resistance. However, these operational conditions do not allow the system to reach the highest electricity generation.

\section{Conclusions}

From the results obtained within this study, the following conclusions can be drawn. The external load has a significant effect on population distribution in MFCs. High external resistance results in the evolution of the microbial population from a more electrogenic to a more fermentative microbial culture. This modification in the population distribution affects all of the operational variables, and is mainly reflected in the current density exerted, which decreased from 0.06 to $0.02 \mathrm{~mA}$. Regarding the power exerted, the system essentially behaves as predicted by the Jacobi Theorem, although the peak in power production was obtained for a wide range of load resistances, from 1000 to $3000 \Omega$, instead of being located at the point where the external and internal resistances meet. Finally, regarding the fuel consumption, its value was virtually independent of the external resistance, although a slight decrease was observed after operation at a high external resistance. Considering that the electricity production significantly decreases when external resistance increases, 
while the fuel consumption decreases only slightly, the system exhibits a lower electrical efficiency after operation at a high external resistance.

Author Contributions: Conceptualization, F.J.F.-M.; data curation, L.F.L.-F. and F.J.F.-M.; investigation, S.P. and L.F.L.-F.; writing — original draft, S.P. and F.J.F.-M.; writing—review and editing, J.N., D.K. and F.J.F.-M. All authors have read and agreed to the published version of the manuscript.

Funding: This research was funded by the European Regional Development Fund and the Junta de Comunidades de Castilla-La Mancha, project grant number SBPLY/19/180501/000254. The funding is gratefully acknowledged.

Conflicts of Interest: The authors declare no conflict of interest.

\section{References}

1. Beegle, J.R.; Borole, A.P. Energy production from waste: Evaluation of anaerobic digestion and bioelectrochemical systems based on energy efficiency and economic factors. Renew. Sustain. Energy Rev. 2018, 96, 343-351. [CrossRef]

2. O'Hayre, R.P.; Cha, S.-W.; Colella, W.; Prinz, F.B. Fuel Cell Fundamentals; John Wiley \& Sons: New York, NY, USA, 2006.

3. Mateo, S.; Rodrigo, M.; Fonseca, L.P.; Canizares, P.; Fernandez-Morales, F.J. Oxygen availability effect on the performance of air-breathing cathode microbial fuel cell. Biotechnol. Prog. 2015, 31, 900-907. [CrossRef]

4. Mateo, S.; Cañizares, P.; Fernandez-Morales, F.J.; Rodrigo, M.A. A critical view on microbial fuel cells: What's the next stage? ChemSusChem 2018. [CrossRef] [PubMed]

5. Mateo, S.; Gonzalez del Campo, A.; Lobato, J.; Rodrigo, M.; Canizares, P.; Fernandez-Morales, F.J. Long-term effects of the transient COD concentration on the performance of microbial fuel cells. Biotechnol. Prog. 2016, 32, 883-890. [CrossRef] [PubMed]

6. Gonzalez del Campo, A.; Lobato, J.; Canizares, P.; Rodrigo, M.A.; Fernandez Morales, F.J. Short-term effects of temperature and COD in a microbial fuel cell. Appl. Energy 2013, 101, 213-217. [CrossRef]

7. Rozendal, R.A.; Hamelers, H.V.M.; Rabaey, K.; Keller, J.; Buisman, C.J.N. Towards practical implementation of bioelectrochemical wastewater treatment. Trends Biotechnol. 2008, 26, 450-459. [CrossRef]

8. Ieropoulos, I.; Greenman, J.; Melhuish, C. Improved energy output levels from small-scale Microbial Fuel Cells. Bioelectrochemistry 2010, 78, 44-50. [CrossRef] [PubMed]

9. Aelterman, P.; Versichele, M.; Marzorati, M.; Boon, N.; Verstraete, W. Loading rate and external resistance control the electricity generation of microbial fuel cells with different three-dimensional anodes. Bioresour. Technol. 2008, 99, 8895-8902. [CrossRef]

10. Khan, M.M.; Ansari, S.A.; Lee, J.H.; Lee, J.; Cho, M.H. Mixed Culture Electrochemically Active Biofilms and their Microscopic and Spectroelectrochemical Studies. Acs Sustain. Chem. Eng. 2014, 2, 423-432. [CrossRef]

11. Khan, M.E.; Khan, M.M.; Cho, M.H. Environmentally sustainable biogenic fabrication of AuNP decorated-graphitic g-C3N4 nanostructures towards improved photoelectrochemical performances. RSC Adv. 2018, 8, 13898-13909. [CrossRef]

12. Khan, M.E.; Han, T.H.; Khan, M.M.; Karim, M.R.; Cho, M.H. Environmentally Sustainable Fabrication of Ag@g-C3N4 Nanostructures and Their Multifunctional Efficacy as Antibacterial Agents and Photocatalysts. ACS Appl. Nano Mater. $2018,1,2912$. [CrossRef]

13. Khan, M.E.; Khan, M.M.; Min, B.K.; Cho, M.H. Microbial fuel cell assisted band gap narrowed TiO2 for visible light-induced photocatalytic activities and power generation. Sci. Rep. 2018, 8. [CrossRef]

14. Gonzalez Del Campo, A.; Perez, J.F.; Cañizares, P.; Rodrigo, M.A.; Fernandez, F.J.; Lobato, J. Characterization of light/dark cycle and long-term performance test in a photosynthetic microbial fuel cell. Fuel 2015, 140, 209-216. [CrossRef]

15. Logan, B.E.; Hamelers, B.; Rozendal, R.; Schröder, U.; Keller, J.; Freguia, S.; Aelterman, P.; Verstraete, W.; Rabaey, K. Microbial fuel cells: Methodology and technology. Environ. Sci. Technol. 2006, 40, 5181-5192. [CrossRef]

16. Clauwaert, P.; Aelterman, P.; Pham, T.H.; De Schamphelaire, L.; Carballa, M.; Rabaey, K.; Verstraete, W. Minimizing losses in bio-electrochemical systems: The road to applications. Appl. Microbiol. Biotechnol. 2008, 79, 901-913. [CrossRef]

17. Lyon, D.Y.; Buret, F.; Vogel, T.M.; Monier, J.M. Is resistance futile? Changing external resistance does not improve microbial fuel cell performance. Bioelectrochemistry 2010, 78, 2-7. [CrossRef]

18. Katuri, K.P.; Scott, K.; Head, I.M.; Picioreanu, C.; Curtis, T.P. Microbial fuel cells meet with external resistance. Bioresour. Technol. 2011, 102, 2758-2766. [CrossRef]

19. Potrykus, S.; Kutt, F.; Nieznański, J.; Fernández Morales, F.J. Advanced Lithium-Ion Battery Model for Power System Performance Analysis. Energies 2020, 13, 2411. [CrossRef]

20. Kook, L.; Nemestothy, N.; Belafi-Bako, K.; Bakonyi, P. Investigating the specific role of external load on the performance versus stability trade-off in microbial fuel cells. Bioresour. Technol. 2020, 309. [CrossRef]

21. Gonzalez del Campo, A.; Fernandez, F.J.; Canizares, P.; Rodrigo, M.A.; Pinar, F.J.; Lobato, J. Energy recovery of biogas from juice wastewater through a short high temperature PEMFC stack. Int. J. Hydrog. Energy 2014, 39, 6937-6943. [CrossRef]

22. Yi, Y.; Xie, B.; Zhao, T.; Li, Z.; Stom, D.; Liu, H. Effect of external resistance on the sensitivity of microbial fuel cell biosensor for detection of different types of pollutants. Bioelectrochemistry 2019, 125, 71-78. [CrossRef]

23. Mateo, S.; Zamorano-López, N.; Borras, L.; Fernandez-Morales, F.J.; Cañizares, P.; Seco, A.; Rodrigo, M. Effect of sludge age on microbial consortia developed in MFCs. J. Chem. Technol. Biotechnol. 2018, 93, 1290-1299. [CrossRef] 
24. Gonzalez del Campo, A.; Perez, J.F.; Canizares, P.; Rodrigo, M.A.; Fernandez, F.J.; Lobato, J. Study of a photosynthetic MFC for energy recovery from synthetic industrial fruit juice wastewater. Int. J. Hydrog. Energy 2014, 39, 21828-21836. [CrossRef]

25. Wang, Z.; Mahadevan, G.D.; Wu, Y.; Zhao, F. Progress of air-breathing cathode in microbial fuel cells. J. Power Sources 2017, 356, 245-255. [CrossRef]

26. Yin, Z.X.; dos Santos, C.E.D.; Vilaplana, J.G.; Sobotka, D.; Czerwionka, K.; Damianovic, M.; Xie, L.; Morales, F.J.F.; Makinia, J. Importance of the combined effects of dissolved oxygen and $\mathrm{pH}$ on optimization of nitrogen removal in anammox-enriched granular sludge. Process Biochem. 2016, 51, 1274-1282. [CrossRef]

27. American Public Health Association, E.A.D.A.W.W.A.W.E.F. Standard Methods for the Examination of Water and Wastewater; APHA-AWWA-WEF: Washington, DC, USA, 2005.

28. Fernandez-Morales, F.J.; Villasenor, J.; Infantes, D. Modeling and monitoring of the acclimatization of conventional activated sludge to a biohydrogen producing culture by biokinetic control. Int. J. Hydrog. Energy 2010, 35, 10927-10933. [CrossRef]

29. Pinto, R.P.; Srinivasan, B.; Manuel, M.F.; Tartakovsky, B. A two-population bio-electrochemical model of a microbial fuel cell. Bioresour. Technol. 2010, 101, 5256-5265. [CrossRef] [PubMed]

30. Sjöblom, M.; Matsakas, L.; Christakopoulos, P.; Rova, U. Production of butyric acid by Clostridium tyrobutyricum (ATCC25755) using sweet sorghum stalks and beet molasses. Ind. Crop. Prod. 2015, 74, 535-544. [CrossRef]

31. Zhang, Y.; Ng, C.K.; Cohen, Y.; Cao, B. Cell growth and protein expression of Shewanella oneidensis in biofilms and hydrogelentrapped cultures. Mol. Biosyst. 2014, 10, 1035-1042. [CrossRef] [PubMed]

32. Schröder, U. Anodic electron transfer mechanisms in microbial fuel cells and their energy efficiency. Phys. Chem. Chem. Phys. 2007, 9, 2619-2629. [CrossRef]

33. Rismani-Yazdi, H.; Christy, A.D.; Carver, S.M.; Yu, Z.; Dehority, B.A.; Tuovinen, O.H. Effect of external resistance on bacterial diversity and metabolism in cellulose-fed microbial fuel cells. Bioresour. Technol. 2011, 102, 278-283. [CrossRef] [PubMed]

34. Infantes, D.; González del Campo, A.; Villaseñor, J.; Fernández, F.J. Kinetic model and study of the influence of pH, temperature and undissociated acids on acidogenic fermentation. Biochem. Eng. J. 2012, 66, 66-72. [CrossRef]

35. González del Campo, A.; Cañizares, P.; Rodrigo, M.A.; Fernández, F.J.; Lobato, J. Microbial fuel cell with an algae-assisted cathode: A preliminary assessment. J. Power Sources 2013, 242, 638-645. [CrossRef]

36. Behera, M.; Ghangrekar, M.M. Performance of microbial fuel cell in response to change in sludge loading rate at different anodic feed pH. Bioresour. Technol. 2009, 100, 5114-5121. [CrossRef]

37. Pinto, R.P.; Srinivasan, B.; Uiot, S.R.; Tartakovsky, B. The effect of real-time external resistance optimization on microbial fuel cell performance. Water Res. 2011, 45, 1571-1578. [CrossRef]

38. Picioreanu, C.; Katuri, K.P.; Head, I.M.; Van Loosdrecht, M.C.M.; Scott, K. Mathematical model for microbial fuel cells with anodic biofilms and anaerobic digestion. Water Sci. Technol. 2008, 57, 965-971. [CrossRef]

39. Picioreanu, C.; Head, I.M.; Katuri, K.P.; van Loosdrecht, M.C.M.; Scott, K. A computational model for biofilm-based microbial fuel cells. Water Res. 2007, 41, 2921-2940. [CrossRef] 